THE INTERNATIONAL JOURNAL UROLOGIC HISTORY

\title{
Adrenaline Rush: the Race for the Crystallization of Adrenal Extracts by J Takamine and K Uenaka
}

\author{
Tetsumori Yamashima1, ${ }^{\star}$, Evan Spencer², John L. Phillips²
}

From the (1) Department of Psychiatry and Behavioral Science, Kanazawa University Graduate School of Medical Sciences, Kanazawa, Japan amd (2) Department of Urology, New York Medical College, Valhalla, NY, USA.

*Correspondence: Tetsumori Yamashima, Takara-machi 13-1, Kanazawa, 920-8041 Japan; e-mail: yamashima215@gmail.com

Introduction: The adrenal gland was first described by Eustachio in 1564, but its physiologic role remained unknown for three centuries. In the late 1890 's, many researchers had directed their attention to the isolation of adrenal extracts, but all failed until the successful efforts of biochemists Jokichi Takamine and Keizo Uenaka. Takamine's patents on Adrenalin were the first ever awarded for a hormone and he used his royalties to improve international relations between America and Japan. There is considerable controversy, however, in how adrenaline was first crystallized, where the work was done, and to whom the credit for its discovery is given.

Sources and Methods: Published contemporary medical literature, newspaper archives, and publicly accessible research archives in Japan, Sweden, and the United States.

Results: Takamine was a multilingual businessman with a background in Western and Eastern medicine, a successful biochemist, and importer/exporter before he took on the project of isolating adrenaline. His successful patents and savvy business acumen allowed him to support innovative research in physiology. He hired Keizo Uenaka, who had experience with isolating ephedrine, to develop the critical methods required to crystallize adrenal extracts where other contemporaries, including Takamine, had failed. Takamine applied for and was awarded five immediate US patents for the discovery although he did not include Uenaka in that effort. Takamine co-founded the Nippon Club and the Japanese Society of New York, both of which ultimately survived the anti-Japanese fervor of the 1940's and, in 1912, worked to bring the gift of 3,000 Japanese cherry trees to Washington, D,C. The Japanese Patent Office honored Takamine as one of Japan's 10 Great Inventors but it was only after Uenaka's death in 1960, and the discovery of his laboratory manuals, was Uenaka's full role in the discovery of adrenaline made known.

Conclusions: Jokichi Takamine was an international benefactor and biochemist extraordinaire who, with Keizo Uenaka, was the first to crystallize adrenal medullary catechols. Takamine's efforts saved lives and did much to engender a spirit of Japanese-American goodwill that persisted for decades.

Keywords: Adrenal, Takamine, Uenaka, Discovery

This work was supported by a grant (TY) from Kiban-Kenkyu (B) (19H04029) from the Japanese Ministry of Education, Culture, Sports, Science and Technology.

A the $52^{\text {nd }}$ annual meeting of the American Medical Association in 1901, Jokichi Takamine (1854-1922), a Japanese-American biochemist and industrial leader, delivered a memorial lecture entitled 'The bloodpressure raising principle of the suprarenal gland' in which he said,

"I am pleased to announce that I have succeeded in isolating the active principle of the gland in a stable, pure, crystalline basic form. .... I have termed the active principle of the gland as I have isolated it, 'adrenalin' .... and is over one thousand times stronger than the fresh glands."(1) Takamine and his young associate, Keizo Uenaka (sometimes written in English as Wooyenaka), crystallized adrenaline (or 'epinephrine' in the United

International Journal of Urologic History(C 2021 ISSN 2769-2183
States) in the summer of 1900, the first hormone ever to be isolated in the twentieth century from animal adrenal tissue. The compound transformed surgery, where it was used very soon thereafter in an attempt to control hemorrhage, the world's first effective asthma medicine, a remedy for anaphylactic shock, and, at least in one pugilist, for ringside boxing injuries.(2) Takamine moved from Japan to the United States to establish a research laboratory in Peoria, Illinois, where he worked to apply a traditional Japanese fermentation technology of sake, based on the aspergillus mold of 'koji', to Western whisky production, which had been based on 'malt'. In 1894, he filed the first patent in the US on a fungal amylase he isolated called Taka-diastase

https://doi.org/10.53101/IJUH.1.2.1152204 Vol. I (2), 58-65, January 2022 Electronically distributed 
critical to a more efficient alcohol distillation but which was more successfully marketed as an aid for dyspepsia. Supported by the pharmaceutical company Parke, Davis \& Co., which purchased the rights to Taka-diastase, Takamine then moved to New York to establish his own laboratory, hired Uenaka, and where they ultimately crystallized adrenal gland extracts. Both 'Taka-diastase' and 'Adrenalin(e)' were ground-breaking innovations and contributed to establishing Takamine's reputation as a leading biochemist in the explosive progress of the early pharmaceutical industry in the twentieth century. This paper aims to better elucidate Takamine and Uenaka's route to the discovery of adrenaline crystals, its controversies, and its impact on the development of the modern pharmaceutical industry.

\section{SOURCES AND METHODS}

A literature review was conducted using the MEDLINE/ PubMed database, the HathiTrust digital library (www. hathitrust.org), and the digital storage site of JSTORG (www.jstor.org) of primary or secondary source materials as cited. United States Patent Office records were searched through the www.uspto.gov portal. Records of Nobel Prize Committee decisions was accessed through the nomination archive at the nobelprize.org/ nomination portal. New York Public Library holdings were searched using the photodatabase at oldnyc.org.

\section{RESULTS}

\section{Anatomic Studies}

The discovery of the adrenal gland itself is generally credited to Eustachi Bartolomeo Eustachio (c.150010-1574) who described the vascular connections of the right and left adrenal in 1564.(3) He described the adrenal as an accessory kidney or 'glandulae renibus incumbentes' and it was not until 1656 when Thomas Wharton (1614-1673) proposed their neuroendocrine function.(3) Thomas Addison (1793-1860) famously noted the stigmata of the disease that bears his name in his landmark 1855 manuscript whereby both adrenal glands are affected by tuberculosis.(4) Albert von Koelliker, in 1852, using an improved compound microscope, was the first to appreciate the distinction between the adrenal cortex and medulla.(5) The great French physiologist Edmé Félix Alfred Vulpian (1826 -1887) demonstrated in 1856 that ferric chloride would not only stain the medulla sea-green but that blood from the adrenal veins provided the same reaction while blood from other organs did not.(6) It was C. F. W. Krunkenberg who first surmised that the 'Vulpian' color reaction of adrenal extracts was similar to that of a common molecule in plants, a pyrocatechol, and that the adrenal medulla must be a source of other catechols. (7) Based on Addison's paper, and Vulpian's findings, there was now great interest that the adrenal cortex and medulla had different effects. Charles-Édouard
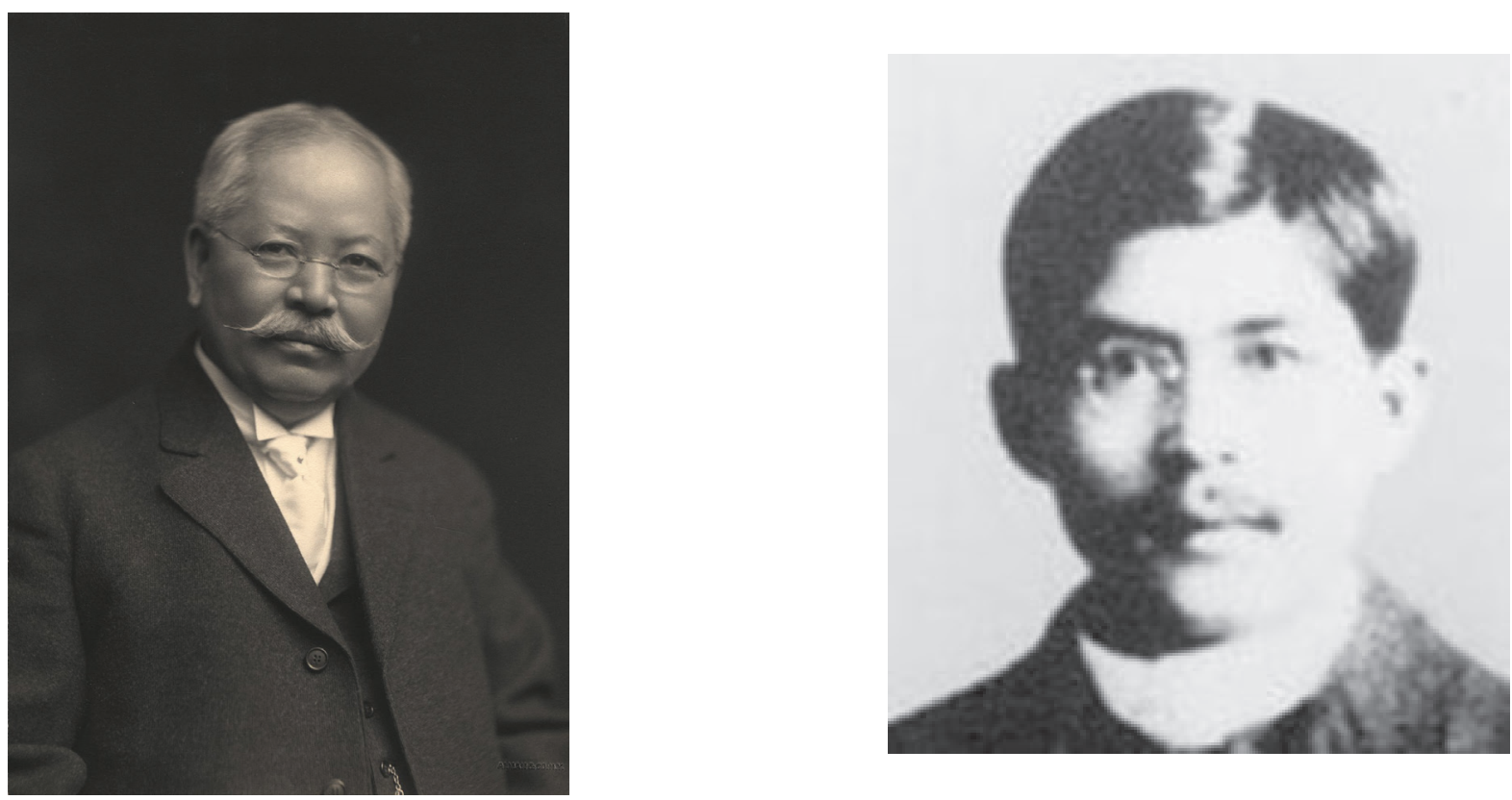

Figure 1. (Left) Jokichi Takamine (1854-1922), already a wealthy import/exporter in the fertilizer business and had patented the pharmaceutical Taka-diastase before tackling the challenge of the adrenal gland. (Right) Keizo Uenaka (1876-1960), the biochemist, hired by Takamine to come to New York and whose diligent efforts led to the first crystallized products of the adrenal gland. (Public domain) 
Brown-Séquard (1817-1894) performed bilateral adrenalectomies in some 60 laboratory animals of different species.(8) None survived and he concluded that adrenal glands maintained a critical role in life by secreting substances into the bloodstream. Thus, by the end of the 19th century, a basic anatomy, histology, and embryology of the adrenal glands was appreciated; their function was not.

\section{Physiologic Studies}

The credit for the first demonstration of the effects of adrenaline is given to George Oliver (1841-1915) and Edward A. Schäfer (1850-1935). Oliver had originally detected a change in radial artery caliber in his adult son who had volunteered to eat extracts of ovine and bovine adrenal extracts from the local abattoir. Oliver journeyed to London in 1893 and worked with Shäffer who himself was engaged in blood pressure research. The adrenal extracts produced a transient hypertension in a dog that was so potent that the mercury column in the manometer almost overflowed.(9) The OliverSchäfer observations, published in 1895 , heralded the first demonstration of the physiologic effects of the adrenal medulla and is regarded as a breakthrough in modern physiology and endocrinology.(10)

\section{The Quest for Purification.}

The effects of adrenal extracts on blood pressure proved to be transient physiologically. The active compounds responsible for such effects proved to be biochemically elusive as well. Otto Von Fürth (1867-1938), Benjamin Moore (1867-1922), and Felix Fränkel were all early physiologists who used basic chemical steps to try and precipitate the active hypertensive agent from adrenal extracts. Fränkel noted that the molecule of interest was a substituted catecol, as Kruckenberg had suggested, and that it was probably a derivative of a larger benzoyl molecule.(11) John J Abel (1857-1938), already famous as Professor of Pharmacology at Johns Hopkins, seized upon Fränkel's hypothesis, and focused on benzoylation procedures in hopes of purifying the active agent of the adrenal medulla. With Albert Crawford, Abel developed a pioneering but complex procedure incorporating benzoyl chloride which yielded a mono-benzoyl crystal he later termed epinephrine-hydrate. $(12,13)$ The extract could raise blood pressure and he was able to calculate the empirical formula for the compound he obtained as $\mathrm{C}_{17} \mathrm{H}_{15} \mathrm{NO}_{4}$ but the derived substance proved less active than crude extracts themselves. The benzoyl process was troublesome for others as well and some, like Fürth, claimed that the 'epinephrine' Abel obtained was not pure, that Abel had obtained an inactive foreign substance, a benzoyl derivative of a

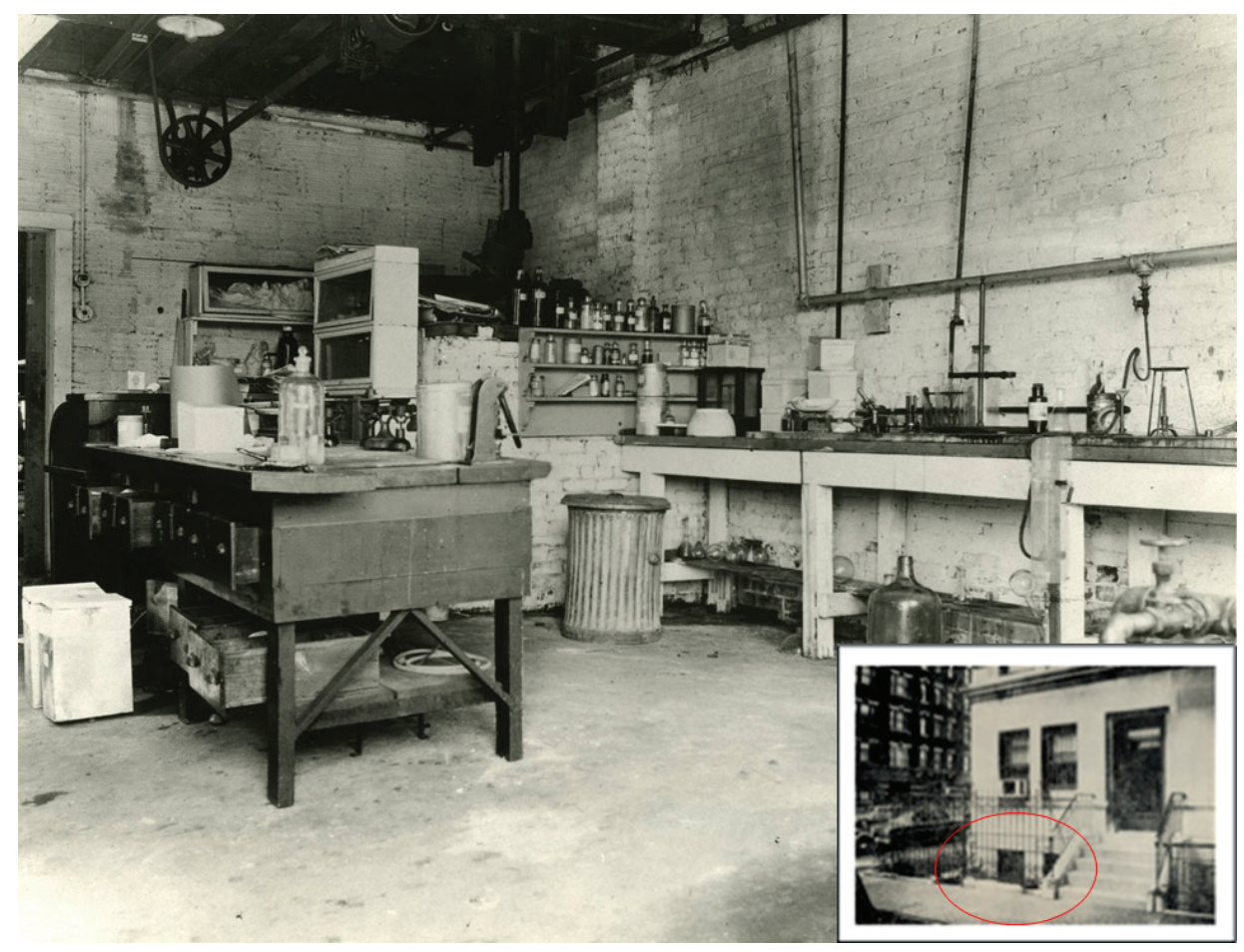

Figure 2. The Takamine Lab. Takamine in 1898 toiled here in a 109th street New York basement lab (see inset) from 1898-1900. He then brought in Uenaka who, within months, elicited a positive Vulpian reaction in a batch of crystals derived from kilograms of adrenal tissue, crystals which eventually yielded the drug Adrenalin and hailed as a modern wonder. (Public domain) 

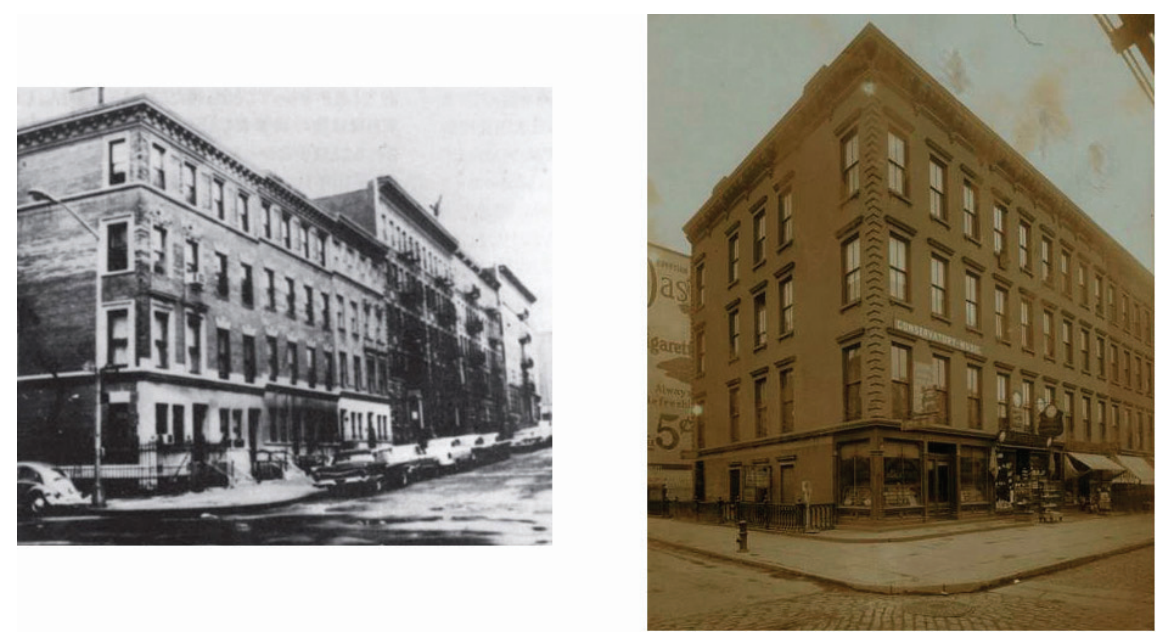

Figure 3. (Left) View of purported Takamine Lab in basement of this 4-story block on northwest corner of East 109th street, New York, NY (Japanese Heritage Foundation) (Right) 1912 view of a building with similar features including the Italienate cornice dentil mouldings prevalent in 19th century Manhattan. (New York Public LIbrary)

compound that had withstood the harsh requirements of a hydrolysis procedure in an autoclave. "The dispute between these two authors," Takamine wrote, "was not altogether amicably solved."(1) Abel himself later termed these struggles as "blunders of a pioneer" but did, as Takamine later wrote, "no doubt thrown some light on the chemical side. Unfortunately, he was not working with the active principle but a somewhat modified substance or the benzoyl-compound: and that these substances were "not crystallizable". $(14,15)$

\section{Takamine and Uenaka}

Jokichi Takamine was originally from Kanazawa and after graduation from Kobu University, was sent on a scholarship to Great Britain where he mastered industrial chemistry. He returned to Japan and, in the Ministry of Agriculture, worked tirelessly to apply modern science and technology to traditional practices. He served as Chief of the Japanese Patent Office and learned early the important relationships between scientific discovery and business. He represented Japan at the World Cotton Convention where he met the New Orleans debutante Caroline Hitch in 1884 and, after their 1887 marriage, the couple lived in Japan for some years while he developed a successful US-Japanese fertilizer business.(16) At the same time, he discovered the enzyme Taka-diastase, an amylase in an aspergillus mold of rice, or ' $k o j i$ ', the active ingredient required to make sake. He found that when applied to the American distillation practice in place of malt, koji could increase the yield and decrease the cost of whiskey production. The couple moved to Chicago to continue his work. Mrs. Takamine, who had campaigned to market her husband and his patents in the US, got a Chicago distillery interested in koji but initial profits were modest. At the same time, Takamine also noticed that Taka-diastase was useful for the treatment of dyspepsia. He himself benefited from the supplement as a sufferer and successfully sold the now patented enzyme to the Detroit-based pharmaceutical company Parke, Davis \& Co.(17,18) The product was successful and, with his fertilization business, Takamine enjoyed substantive wealth. Meanwhile, Parke, Davis's general manager, William Warren, was intrigued by the blood pressure raising properties of animal adrenal tissues and, in 1897, asked Takamine to study in detail the papers of Moore, Fürth, and Abel. Now financially able to do so, Takamine moved his wife and two sons to 475 Central Park West, New York City and started his own lab in a $15 \mathrm{~m}^{2}$ semi-underground room at East 109 street where he immersed himself for nearly 2 years in toil.(18) He floundered in perfecting the process of isolating anything active from large volumes of adrenal tissues. He therefore contacted the revered head of the Tokyo Imperial University, Professor Nagayoshi Nagai, with whom Takamine had earlier co-founded the Tokyo Chemical Society and who, in 1885 , had famously discovered ephedrine, the phenylethylamine derivative from the Chinese herb Má huáng (Ephedra vulgaris).(19) 
Nagai had been mentoring a brilliant 24-year old chemist from Nashio-Nishinomiya named Keizo Uenaka (1876-1960) whom Nagai immediately offered up to Takamine.(18) Not only was Uenaka willing to move 12,000 miles away to Manhattan but he began detailed laboratory manuals in classical Japanese chronicling his work with Takamine, a record still kept in the Kyougyou-ji Buddhist archive in Uenaka's native Nashio.(20)

\section{The Manhattan 'Adrenal' Project}

Ueneka arrived in Manhattan in February, 1900 and began work in the lab in July utilizing the experimental procedures which he had mastered during ephedrine isolation with Nagai. Without modern air conditioning, and keeping all the windows closed for fear of excessive oxidation, Uenaka labored that first summer in the semi-underground laboratory, urged on by Takamine who supplied kilograms worth of bovine adrenal tissues from Parke, Davis \& Co (Figure 2, 3). In Uenaka's manuals, he described how he first rejected the harsh sodium hydroxide alkalinizing step of Takamine's, and instead opted to macerate half the adrenal samples in water at $75 \sim 85^{\circ} \mathrm{C}$ for 8 hours; the other half in incubated in $95 \%$ alcohol at $82^{\circ} \mathrm{C}$ for 6 hours. The "alkaline liquid was left overnight until crystal precipitates were observed the following morning. The crystals were filtered with a paper, washed with water, and dried to generate a slightly brownish crystalline powder" via vacuum evaporation. $(20,21)$

On the morning of August 4th, 1900, Uenaka exposed the crystals to ferric chloride and they turned green, a positive 'Vulpian' reaction. On August $13^{\text {th }}$, he utilized ammonia to improve crystallization. Takamine wrote that the product was "astoundingly strong....A fraction of one drop of (the) aqueous solution blanches the normal conjunctiva (of a mouse) within one minute... Three intravenous injections of 1 c.c. of the 1:100,000 solution in an 8 kilogram dog raised the blood pressure corresponding to 30 millimeters of mercury." Uenaka worked on optimizing the process over the next few months and ensured the derived products were different than Professor Abel's. Uenaka even took the daring step of experimenting on himself. "A drop of 1:1,000 acid solution of the new crystals was placed in one of my eyes," Ueneka wrote on October 13"th 1900 "(and) a drop of the aqueous extract of the (non-concentrated gland products) in another eye. The new crystal showed a stronger discoloration (of the eye) than the aqueous extract. So, it was concluded that the optimal dilution of new crystals for practical use should be 1:1,000." Prompted by the potentially exciting findings, Thomas Bell Aldrich, a former assistant to John Abel, and now working at Park, Davis, used a method slightly different from that of Takamine and Uenaka's to isolate crystals from the adrenal gland. Aldrich's end product was very similar to that of Takamine, their empircal formulas being $\mathrm{C}_{9} \mathrm{H}_{13} \mathrm{NO}_{3}$ and $\mathrm{C}_{10} \mathrm{H}_{15} \mathrm{NO}_{3}$, respectively, with the difference later determined to be due to a small amount of contaminating catechols (norepinephrine) in Ueneka's process. However, Aldrich did give credit to Takamine for being the first to derive crystallized adrenal extracts (without crediting Uenaka) and Takamine quickly moved to patent the "Glandular Extractive Product" as its

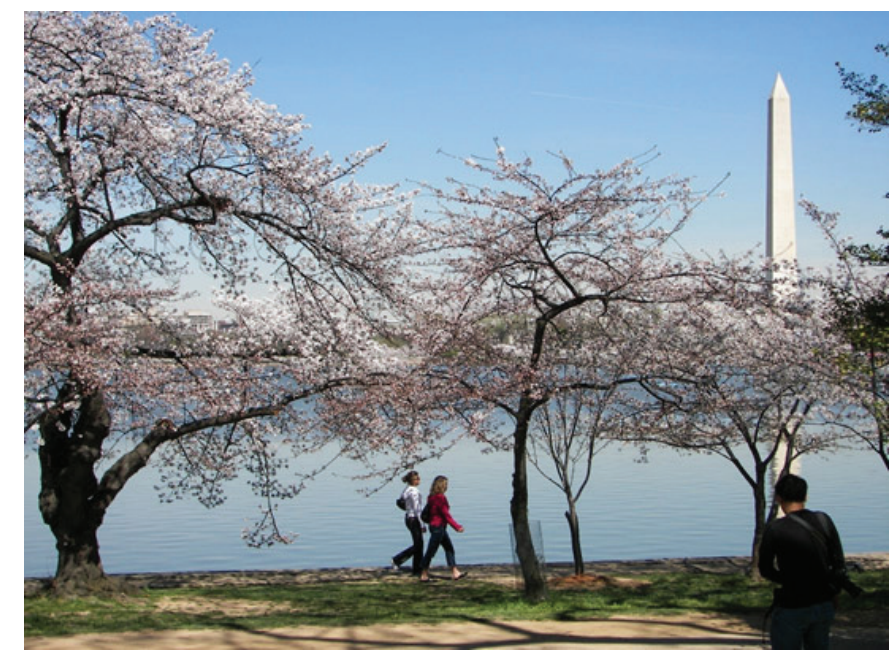

Figure 4. Cherry Trees around the Tidal Basin, Washington D.C. Takamine was a great philanthropist and famously arranged the Japanese donation of thousands of cherry trees to the United States in 1912. (T. Yamashima) 
sole discoverer on November 5th, 1900 even prior to publication of the findings in academic journals.(22) He describes the step-wise process of obtaining the adrenal gland products in the first person singular only; there is no mention of the name "Uenaka". On November 7th, 1900, Ueneka writes that a friend of Takamine's, a certain Dr. Wilson, suggested a new name for the adrenal crystals and the term 'Adrenalin' came into existence. For fear of affecting Takamine's patent application, originality, and reputation, Uenaka dared not disclose the presence of his own Memorandum detailing his critical efforts, and he continued work on optimization steps. Only after Uenaka's death in 1960, when his son Mioji discovered the worn diaries, and provided them for translation from classic to modern Japanese by Aiko Yamashita, was the world informed of the true adrenaline discovery story. $(21,23)$

\section{Controversy}

Takamine recognized the industrial value of adrenaline as he had of Taka-diastase years earlier. He completed five patent aplications for his extract (all of which were approved by June, 1903) and, by 1920, a total of eight patents would be filed and awarded. The discovery secure, Takamine and Ueneka moved back to Parke, Davis \& Co. headquarters in Detroit in December, 1900 to continue the purification processes, presumably also with the help of Thomas Aldrich. Although the US patent office recognized Takamine's claims, rivals, including H.K. Mulford, contended one could not 'patent' a naturally occurring substance. The preeminent federal judge B.L. Hand (1872-1961) ultimately ruled in favor of Takamine but may have established a precedent for subsequent discoveries in nature so patented.(24) Meanwhile, at Park, Davis headquarters, the crystallization process was ramped up and nearly 200 grams of adrenaline crystal could be obtained from 8-20 kilograms of tissue or nearly 30 times what Uenaka alone could produce back in New York. In 1903, Abel formally admitted in a German chemical journal that "(we) owe to Takamine (the) important observation that the substance can be precipitated in crystalline form from concentrated gland extracts by the aid of ammonia and other alkalies. (In German)" (25)

In 1927, five years after Takamine's death, however, Abel wrote "the medullar hormone is called by various names (including) adrenaline and epinephrine, the latter...coined by me thirty years ago at a time when I supposed that the form in which I succeeding in isolating it represented the base as it actually exists in the capsules." It was at this time that Abel recalled receiving Takamine as a visitor in the fall of 1900 and that Takamine "examined with great interest the various compounds and salts of epinephrine that were placed before him. He inquired particularly whether I did not think it possible that my salts of epinephrine could be prepared by a simpler process than mine, more especially without the troublesome and in this case wasteful process of benzoylating extracts of an animal tissue. He remarked in this connection that he loved to plant a seed and see it grow in the technical field."(14) By the time time of Takamine's purported 1900 visit to Abel's lab, however, Uenaka had already derived the product that would ultimately be known as adrenaline. Still, Abel felt that "Takamine should have been successful only after his visit to my laboratory." With Abel's influence in international academic chemistry, his claim of being the first to isolate and name albeit an impure form of epinephrine, and Takamine's trademarking of the word "Adrenalin", "Epinephrine" gradually replaced "adrenaline" in the scientific literature. $(2,26)$

\section{Legacies}

Takamine's investment in so many patents for Adrenalin paid off as the drug became widely employed in the medical community. Takamine used the royalties to enlarge his pharmaceutical research and business, but also to promote Japanese-American friendship. He founded the Nippon Club in 1905 and the Japan Society in 1907 both of which are active today in midtown New York City, although an earlier building had been shuttered by the United States in December, 1941. In 1912, Takamine played a major role in quietly obtaining the Japanese gift of thousands of cherry trees to the United States, trees which famously transformed West Potomac Park and the Tidal Basin in Washington, D.C. (Figure 4) $(2,18)$ Takamine himself had long suffered from liver ailments having undergone surgery for an acute condition in Chicago in the 1890's. He eventually succumbed to the disease on July $22^{\text {nd }}, 1922$ surrounded by his wife and their two sons in Lenox Hill Hospital. A memorial was held at the Nippon Club for the chemist, "perhaps the best-known Japanese in (the) country," before a funeral at St Patrick's Cathedral as Takamine had earlier converted to Catholicism.(27) He was buried at the Takamine family plot in the Bronx's Woodlawn Cemetery although his family deferred the scientist's desire that his body be used for science.(Figure 5) 


\section{DISCUSSION}

The combination of hypothesis-testing and empiricism lie at the heart of scientific advancement. This manuscript portrays the isolation of adrenaline not as an isolated scientific leap, but after dogged, timeconsuming research by Jokichi Takamine and Kezio Uenaka using the most basic chemical processes of the early 20th century. Takamine was a brilliant and pragmatic visionary who saw the isolation of adrenaline for its physiologic significance as well as its financial potential. Such a great discovery for mankind did not come without its controversies.

Takamine, for one, was Uenaka's employer suggesting a very intimate, trusting relationship between the two men. Uenaka may not have been fully aware of Takamine's objective to obtain a patent and gave Takamine the detailed information of the crystallization procedures described in both Uenaka's 'Experimental Memorandum' and Takamine's 'Laboratory Diary'. Some have surmised that Uenaka wished to protect Takamine's patent application, originality, and reputation, and dared not disclose the existance of his own Memorandum before and even after Takamine's death in 1922. It was only after Ueneka's own passing, in 1960, when his son Mioji found and reproduced his father's' laboratory manuals that Uenaka's true contribution to science became known. (20)

Abel himself appeared somewhat skeptical of the speed Takamine rushed to patent his findings, a feeling he articulated more widely after Takamine's death in 1922. As a professor of pharmacology at Johns Hopkins University, and a prolific writer, Abel's mindset was to publish scientific papers, not focus on patents and royalties.(14) Abel implicated that Takamine stole his technique of using ammonia at the final process of precipitation, suggesting that Takamine's achievement was essentially a copy of his experimental procedure. Since Takamine and Uenaka had already isolated adrenaline crystals before Takamine visited Abel's laboratory, Abel's position on any conceptual theft seems less likely. Abel's own efforts to purify adrenaline were stymied by contaminating benzoyl derivatives, but so too were Uenaka's adrenaline crystals slightly contaminated with noradrenaline which explained differences in chemical formulas when Aldrich tried his hand at the purification step later. Only the more sophisticated techniques of the 1940s, used by Ulf Svante von Euler (1873-1964), was finally able to differentiate and purify noradrenaline from adrenaline. Von Euler who was the first to demonstrate that noradrenaline is the main neurotransmitter in the sympathetic nervous system, and for such work was awarded the Nobel Prize in 1970, some 70 years after Takamine and Uenaka's discovery.(28) Abel himself was nominated for the Nobel prize on at least 12 different occasions in the 1920s; Takamine never lived to see such an honor.

As written in a 1928 remembrance, "Time will dim the memory of his face, but it will only multiply his service to mankind, for wherever the substances of his discovery are used to assist a surgeon or physician, there will Dr. Takamine be present (John H. Finley).(17)

As for Uenaka, he appears to have continued his work at Parke, Davis until 1916 when he relocated back to Japan to work in Sankyo Pharmaceutical Company (now Daiichi Sankyo) which Takamine had founded in

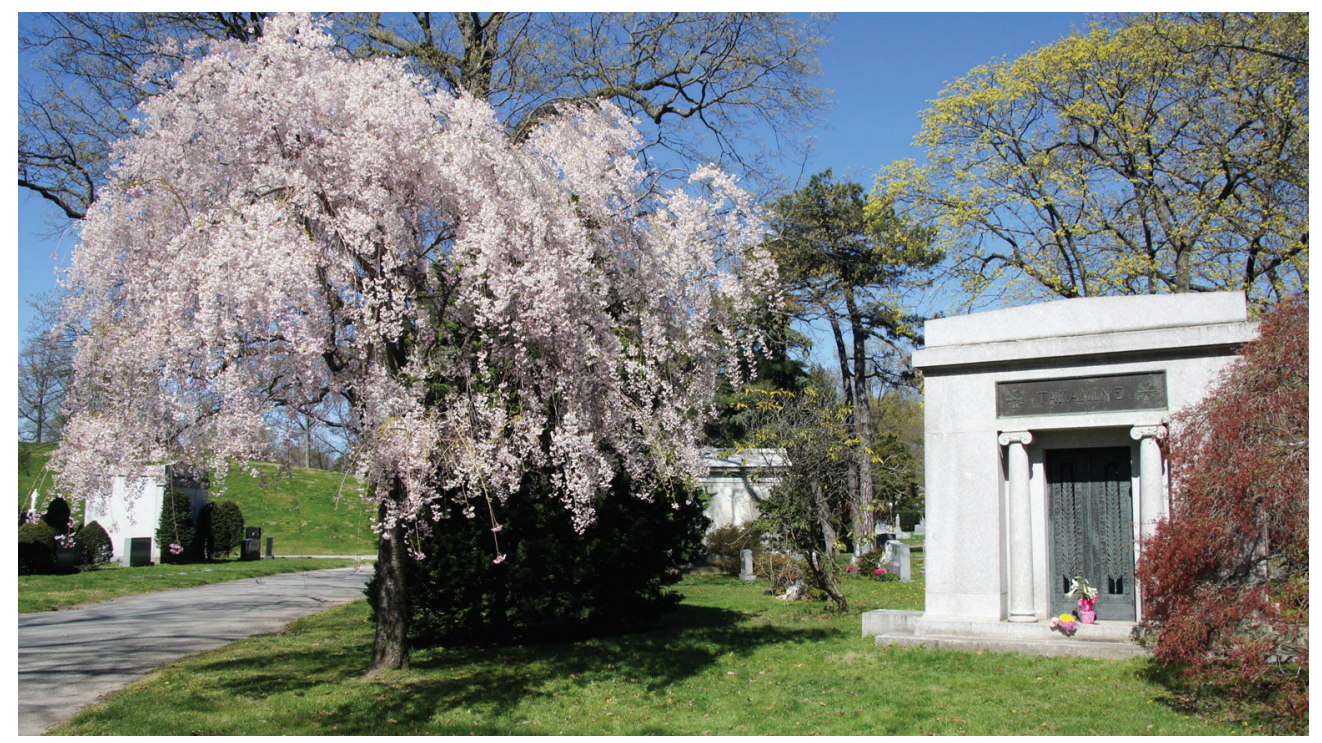

Figure 5. Final resting place of Jokichi Takamine, Takamine plot, Bronx's Woodlawn Cemetary. (T.Yamashima) 
1913. But the deprivations of the second world war was difficult for Uenaka and his family, at times relegated to forging for edibles in the woods.(29) Uenaka appears to have been resigned to relative obscurity, working in his native province and living into his eighties. He made no subsequent claims to the discovery of adrenaline, even after Takamine's death, and his famous laboratory manuals may have perished were it not for the archival efforts of his son.

\section{CONCLUSIONS}

Jokichi Takamine and Keizo Uenaka were the first to crystallize adrenal extracts, Takamine for enabling the effort and patenting the discovery, and Ueneka for optimizing the technical steps for the process at the dawn of modern organic chemistry.

\section{REFERENCES}

1. Takamine J: The blood-pressure raising principle of the suprarenal gland. JAMA - Journal of the American Medical Association 1902; 38: 153.

2. Bennett J: Adrenaline and Cherry Trees. Modern Drug Disc 2001; 4: 47.

3. Wharton T: Glandularum totius corporis descriptio. Amsterdam: S.J. Ravesteinii 1659 (see anatomia.library. utoronto.ca).

4. Addison T: On the constitutional and local effects of disease of the suprarenal capsules. In: R.H. Major (Ed.). Classic descriptions of disease, 3rd edition. Springfield: C.C. Thomas, 1959.

5. Von Kölliker A: Handbuch der Gewebelehre des Menschen. Leipzig: W Engelmann 1852.

6. Vulpian E: Note sur quelques réactions propres à la substance des capsules surrénales, Comptes rendus hebdomadaires des séances de l'Académie des sciences, 1856. In: T. Morton (Ed.) A Medical Bibliography. Philadelphia: JB Lippincott 1970.

7. Krunkenberg C: Die farbige Derivaten der Nebennierenchromogene. Archiv Pathol Anat Phys Klin Med 1885; 101: 542 .

8. Brown-Séquard CE: Recherches experimentale sur la physiologie et la pathologie des capsules surrenales. Archiv Generales Med 1856; 5: 385.

9. Sherrington CS: Sir Edward Sharpey-Schäfer and his contributions to neurology. Edinburgh Med Journal 1935; 42: 393.

10. Oliver G, Schäfer EA: The physiological effects of extracts of the suprarenal capsules. J Physiol 1895; 18: 230.

11. Fränkel S: Physiological action of supra-renal capsules. J Chem Soc 1897; 72: 63.
12. Abel J: Über den Blutdruckerregenden Bestandheil des Nebenniere, das Epinephrin. Ztschr Physiol Chem 1899; 28: 318.

13. Abel J: Further observations on the chemical nature of the active principles of the suprarenal capsule. Bull Johns Hopkins Hosp 1898; 9: 215.

14. Abel J: Chemistry in relation to biology and medicine with especial reference to insulin and other hormones. Science 1927; 66: 337.

15. Takamine J: Adrenalin, the active principle of the suprarenal glands and its mode of preparation. Amer J Pharm 1901; 73: 523.

16. Shurtleff W, Aoyagi A: Jokichi Takamine (1854-1922) and Caroline Hitch Takamine (1866-1954): Biography and bibliography. Lafayette, California: Soylnfo Center, 2012 (see soyinfocenter.com/book/155).

17. Kawakami KK: Jokichi Takamine. A record of his American achievements. New York: William Edwin Rudge 1928.

18. Yamashima T: Jokichi Takamine (1854-1922), the samurai chemist and his work on adrenalin. J Med Biography 2003; 11: 95.

19. Lee MR: The history of Ephedra (ma-huang). J Roy Coll Phys Edinb 2011; 41: 78.

20. Mieda R, Aso C, Hiroki, Kanamoto M, Suto T, Tobe $M$, Saito S: Comparison of four documents describing adrenaline purification, and the work of three important scientists, Keizo Uenaka, Nagayoshi Nagai, and Jokichi Takamine. J Anesth History 2020; 6: 42.

21. Yamashita A: Research note on adrenalin by Keizo Uenaka in 1900. Biomed Research 2002; 23: 1.

22. Takamine J: Process of Obtaining Products from Suprarenal Glands, United States Patent \#730175. United States Patent and Trademark Office. June $2^{\text {nd }}, 1903$.

23. Nakayama S: The cultural heritage of Japan registered by the National Science Musuem of Japan. No. 002: "On Adrenalin Memorandum, July to December 1900" by Keizo Uenaka, and stored in the temple at Kyogyouji. Kagaku-to-Kogyo 2010; 63: 558.

24. Contreras J: The Genome Defense. Chapel Hill: Alconquin Books of Chapel Hill, pp 51-52, 2021.

25. Abel J: Weitere Mittheilungen über das Epinephrin. Berichte Deutschen Chem Gesellschaft Berlin 1903; 36: 1839.

26. The propaganda for reform. JAMA - Journal of the American Medical Association 1911; 56: 910.

27. New York Times, July 23, 1922, p 19

28. Archives of the Nobel Prize Committee, Stockholm, 2021 See nobelprize.org/nomination/archive

29. Bennett J: personal communication, JB to Ed. 2021. 